\title{
Immune-Boosting, Antioxidant and Anti-inflammatory Food Supplements Targeting Pathogenesis of COVID-19
}

\author{
M. Mrityunjaya ${ }^{1,2}$, V. Pavithra ${ }^{1,2}$, R. Neelam ${ }^{1}$, P. Janhavi ${ }^{1,2}$, P. M. Halami ${ }^{3}$ and \\ P. V. Ravindra ${ }^{1 *}$ \\ ${ }^{1}$ Department of Biochemistry, Council of Scientific and Industrial Research-Central Food Technological Research Institute, \\ Mysuru, India, ${ }^{2}$ Academy of Scientific and Innovative Research, Ghaziabad, India, ${ }^{3}$ Department of Microbiology and \\ Fermentation Technology, Council of Scientific and Industrial Research-Central Food Technological Research Institute, \\ Mysuru, India
}

OPEN ACCESS

Edited by:

Alexandros Tsoupras,

University of Limerick, Ireland

Reviewed by:

Laura Baldomà,

University of Barcelona, Spain José Parente,

Federal University of Rio de Janeiro, Brazil

*Correspondence:

P. V. Ravindra

raviravindra1@gmail.com

Specialty section:

This article was submitted to Nutritional Immunology,

a section of the journal

Frontiers in Immunology

Received: 06 June 2020 Accepted: 25 August 2020 Published: 07 October 2020

Citation: Mrityunjaya M, Pavithra V, Neelam R, Janhavi $P$, Halami $P M$ and Ravindra PV (2020) Immune-Boosting, Antioxidant and Anti-inflammatory Food Supplements Targeting Pathogenesis of COVID-19.

Front. Immunol. 11:570122.

doi: 10.3389/fimmu.2020.570122
The COVID-19 is an acute and contagious disease characterized by pneumonia and ARDS. The disease is caused by SARS-CoV-2, which belongs to the family of Coronaviridae along with MERS-CoV and SARS-CoV-1. The virus has the positive-sense RNA as its genome encoding for $\sim 26$ proteins that work together for the virus survival, replication, and spread in the host. The virus gets transmitted through the contact of aerosol droplets from infected persons. The pathogenesis of COVID-19 is highly complex and involves suppression of host antiviral and innate immune response, induction of oxidative stress followed by hyper inflammation described as the "cytokine storm," causing the acute lung injury, tissue fibrosis, and pneumonia. Currently, several vaccines and drugs are being evaluated for their efficacy, safety, and for determination of doses for COVID-19 and this requires considerable time for their validation. Therefore, exploring the repurposing of natural compounds may provide alternatives against COVID-19. Several nutraceuticals have a proven ability of immune-boosting, antiviral, antioxidant, anti-inflammatory effects. These include Zn, vitamin D, vitamin C, curcumin, cinnamaldehyde, probiotics, selenium, lactoferrin, quercetin, etc. Grouping some of these phytonutrients in the right combination in the form of a food supplement may help to boost the immune system, prevent virus spread, preclude the disease progression to severe stage, and further suppress the hyper inflammation providing both prophylactic and therapeutic support against COVID-19.

Keywords: SARS-CoV-2, COVID-19, pathogenesis, food supplements, immune-boosting, antioxidant, anti-inflammation

\section{SEVERE ACUTE RESPIRATORY SYNDROME-CORONAVIRUS (SARS-COV)-2 INFECTION}

The coronavirus disease (COVID-19) was first reported in late 2019 from Wuhan's city in China. Thus far, the infection has spread to almost all countries globally and was declared a pandemic by the WHO. While writing this review, there were more than $23 \mathrm{M}$ confirmed cases and more than $800 \mathrm{~K}$ deaths. In India, there were more than $3 \mathrm{M}$ positive cases, and more than $57 \mathrm{~K}$ reported deaths. The mortality rate of $2-16 \%$, the rapid spread of the disease and high mortality in the susceptible population (mainly aged over 60 years and also in patients with underlying medical conditions including diabetes, cardiovascular diseases, etc.,) has resulted in a global lockdown and life has come to a standstill causing yet another world economic recession after 2008 . The incubation period 
is presumed to vary between 2 and 14 days. The transmission mode includes surface contact of aerosol droplets from infected persons, followed by touching nose, eyes, and mouth. Evidence also points toward vertical transmission to new-borns, also by fecal transmission (1-3). Coronaviruses are enveloped and possess positive-sense single-stranded RNA ( + ssRNA) as their genome. These viruses belong to the large family of Coronaviridae and subfamily Coronavirinae, which infect birds and mammals. The genome size of these viruses ranges from 26 to $32 \mathrm{~kb}$ (4). The virus binds to angiotensin-converting enzyme 2 (ACE2) receptors on cells through its spike (S) glycoprotein. The S protein has two domains S1 and S2. S1 binds to the peptidase domain of ACE2, which is called the receptor-binding domain (RBD), while S2 catalyzes the membrane fusion, thereby releasing the genetic material into cells (5). Inside the cell, the RNA provides the template for structural proteins such as replicase (R1a/ab), envelope (E), Spike (S), membrane (M), nucleoprotein $(\mathrm{N})$, and several non-structural proteins (NSPs 116), uncharacterized protein 14 , protein $9 \mathrm{~b}$ (6). Of them, nonstructural proteins are predicted to participate in the host-protein interactions and modulate host cell signaling pathways. The onset of clinical disease and its progression to the severe stage may vary between individuals and that depend upon their immune status, and the presence of underlying medical conditions. In general, the typical clinical symptoms include, dry cough (67\%), fever (88\%), fatigue (38\%), myalgias (14.9\%), Dyspnoea (18.7\%), other symptoms include, headache, sore throat, rhinorrhoea, and gastrointestinal symptoms. Pneumonia is severe manifestation of the infection (2).

\section{PATHOGENESIS OF COVID-19}

The details of the pathogenesis of SARS-CoV-2 infection is not clearly understood. The available evidence suggests that the pathogenesis of infection can be classified into two phases. Phase 1: An asymptomatic phase with or without detectable virus. Phase 2: Symptomatic phase with high viral load (4). The virus enters the airway epithelium after binding its $S$ protein to the ACE2 receptors and subsequent priming by the cellular transmembrane protease, serine 2 (TMPRSS2). Following its entry, the virus inhibits or delays the host innate interferon (IFN) immune response. The mechanisms of how it modulates the host IFN response is not completely understood. Available evidence from other members of the same family suggests that, the virus inhibits the production of type 1 IFN as well as the signaling downstream of the interferon- $\alpha / \beta$ receptor (IFNAR) (7). The virus interferes with downstream signaling by ubiquitination and degradation of RNA sensor adaptor molecules such as mitochondrial antiviral-signaling (MAVS) protein and tumor necrosis factor receptor-associated factors (TRAF) $3 / 6$ and inhibiting interferon regulatory factor (IRF) 3 nuclear translocation (8). Once type 1 IFN is secreted, the virus interferes IFN signaling by inhibiting signal transducer and activator of transcription (STAT) 1 phosphorylation (9). The viral proteins that modulate host type 1 IFN responses include structural (such as $\mathrm{M}, \mathrm{N}$ ) and NSPs. Following the impairment in the IFN system, virus replication ensues in cells. The viral replication, in turn, triggers the activation of monocytes, macrophages, granulocytes resulting in the hyper inflammatory condition described as "cytokine storm" with the massive secretion of pro-inflammatory cytokines including interleukin (IL)-1, IL-6, IL-8, IL-12, tumor necrosis factor (TNF)- $\alpha$, etc. This results in hyper inflammation of tissues and subsequent tissue fibrosis and pneumonia $(4,7$, 10). Studies also indicate the involvement of oxidative stress in the pathogenesis of COVID-19. Available evidence suggests that, SARS-CoV-2 infection causes oxidative stress directly by enhancing the production of reactive oxygen species (ROS) (11) and indirectly by suppressing the host antioxidant defense mediated by the nuclear factor (erythroid-derived 2)-like 2 (NRF-2) (10). Further, granulocytosis in response to SARS$\mathrm{CoV}-2$ infection also contributes to the production of super oxide ions, a type of ROS and for the additional production of pro-inflammatory cytokines (12). In a study by Lin et al. (13) showed that a viral protease 3CLpro causes a significant increase in the ROS production in HL-CZ cells. Further, study also found that elevated oxidative stress results in activation apoptosis and inflammation. In another study done on human HCoV-229E infection shows that deficiency in the expression of NRF-2 target, glucose-6-phosphate dehydrogenase (G6PDH) results in enhanced ROS as well as virus production (14). Incidentally, the NRF-2 levels were found to be suppressed in lung biopsies from COVID-19 subjects, on the other hand NRF2 activators found to inhibit replication of SARS-CoV-2 and the inflammatory response (10). However, it is not known how SARS-CoV-2 infection causes suppression of NRF-2 signaling. Additionally, studies also suggest that SARS-CoV-2 infection triggers the activation of NF- $\mathrm{KB}$-toll-like receptor (TLR) signaling pathways to induce the oxidative stress and hyper inflammatory response, ultimately leading to acute lung injury (11).

The elevated cytokines also trigger induction of endothelium HA-synthase-2 (HAS2) in alveolar epithelial cells (type 2), and fibroblasts (15). Most importantly, key molecule hyaluronan (HA) has high water binding capacity up to 1,000 times its molecular weight. Perhaps the accumulation of fluid in the lungs could be the reason that computer tomography (CT) images of the lung in acute respiratory distress syndrome (ARDS) patients show the presence of distinguishing white patches called ground glass (16). The majority of autopsies have shown that infected lungs are filled with clear liquid jelly, which resembles the lungs of wet drowning (17). Even though the nature of clear liquid jelly is not yet been determined, $\mathrm{HA}$ is associated with ARDS (18). The lungs of COVID-19 patients show elevated levels of inflammatory cytokines (IL-1, TNF- $\alpha$ ). This correlates with increased activity of HAS2 and the subsequent lung pathology induced by the SARS-CoV-2 infection. Therefore, the above clinical and research findings suggest that COVID-19 pathogenesis involves two phases: Phase 1, suppression of innate immune response, increases in oxidative stress and phase 2 acute inflammation-driven damaging phase (Figure 1).

\section{STRATEGIES TO COUNTERACT THE SARS-COV-2 INFECTION USING FOOD SUPPLEMENTS}

From the point of prevention, phase 1 is crucial as individuals in this stage are carriers, they can spread the infection 


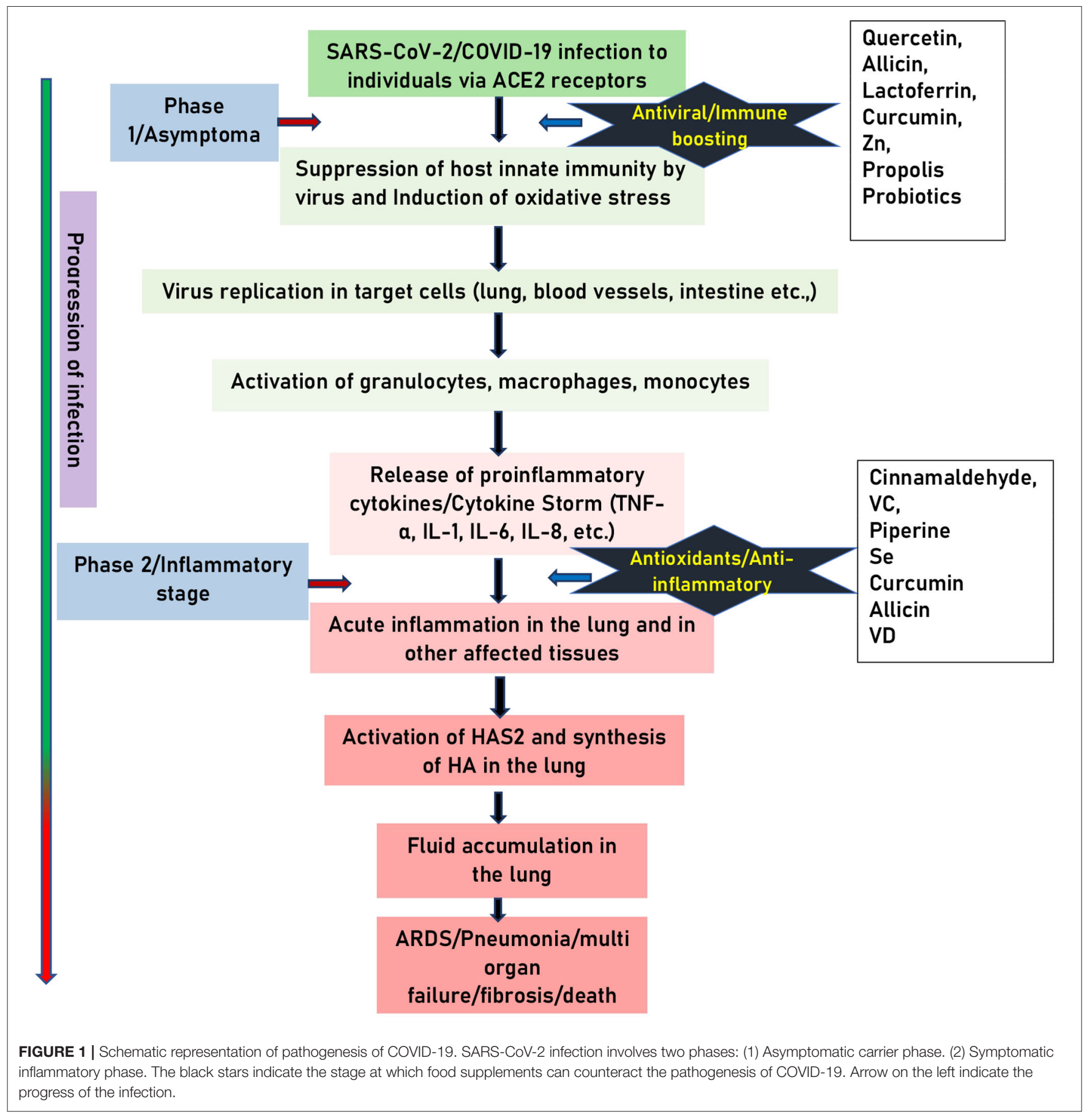

unknowingly. Management of individuals in phase 1, along with mounting specific adaptive immune response, and use of antivirals is critical to prevent the virus entry, replication as well as the disease progression to phase 2. Therefore, global strategies may include administration of external antiviral, and or immune-boosting food supplements. During the phase 2 of the infection, in addition to maintaining the general health condition of affected patients, the line of treatment may be focused on adapting the strategies including the use of nutritional supplements that can suppress the ongoing oxidative stress, acute-inflammation and cytokine storm so that destruction and damage caused to affected tissues is prevented. In summary, in addition to symptomatic treatment, strategies to counteract the SARS-CoV-2 infection is to boost the immune response in phase 1 while suppressing it in the second phase could be effective. 


\section{IMMUNE-BOOSTING, ANTIOXIDANT AND ANTI-INFLAMMATORY FOOD SUPPLEMENTS AGAINST COVID-19}

Currently, there is one vaccine; Sputnik V, approved by the Ministry of Health, Russian Federation. It was fast-tracked for use as a corona vaccine, but experts have expressed concern about the vaccine's efficacy and safety since it has not yet been evaluated in phase 3 clinical trials. Currently, most countries around the world are into developing corona vaccines, a few of them have entered into human trials while most of them are in various stages of research and development. Further, there no specific drug for use against COVID-19 as well as substantial data both at the national or international level on the effects of nutritional supplements on risk or severity of COVID-19. The development of new antivirals for COVID-19 is a great challenge and needs a considerable length of time and effort for designing and validation. Several shreds of evidence indicate that many nutritional supplements from various spices, herbs, fruits, roots, and vegetables can reduce the risk or severity of a wide range of viral infections by boosting the immune response, particularly among people with inadequate dietary sources and also by their anti-inflammatory, free radical scavenging, and viricidal functions. These nutrients can be repurposed in mitigating the pathological effects induced by the SARS-CoV-2 infection. Therefore, the use of natural compounds may provide alternative prophylactic and therapeutic support along with the therapy for COVID-19. In the following section, the beneficial effects of some of the nutrients are described.

\section{ZINC (ZN)}

Zinc is an essential metal involved in a variety of biological processes due to its function as a cofactor, signaling molecule, and a structural element. It regulates inflammatory activity and has antiviral and antioxidant functions (19). Studies in the rat model show that deficiency of $\mathrm{Zn}$ increases oxidative stress, pro-inflammatory TNF- $\alpha$ and vascular cell adhesion molecule (VCAM)-1 expression and causes lung tissue remodeling which was partially reversed by the $\mathrm{Zn}$ supplementation (20). Zn deficiency shows up-regulation of TNF- $\alpha$, IFN- $\gamma$, and FasR signaling and induction of apoptosis in lung epithelial cells (21) and also up-regulates the Janus kinase (JAK)-STAT signaling in lungs under septic conditions (22). Zinc can also modulate the viral entry, fusion, replication, viral protein translation and virus budding of respiratory viruses $(19,23)$. Speth et al. (24) demonstrated that $\mathrm{Zn}$ exposure $(100 \mu \mathrm{M})$ was shown to reduce recombinant human ACE-2 activity in rat lungs. $\mathrm{Zn}^{2+}$ cations especially in combination with $\mathrm{Zn}$ ionophore pyrithione were shown to inhibit SARS-coronavirus RNA polymerase (RNA dependent RNA polymerase, RdRp) activity by suppressing its replication (25). Studies have shown that oral supplementation of $\mathrm{Zn}$ reduces the occurrence of acute respiratory infections by $35 \%$. Zn also shortens the duration of flu-like symptoms by 2 days as well as improves the rate of recovery (26). The recommended dose from various studies ranges from 20 to $92 \mathrm{mg} /$ week (27).
Zinc is considered as the potential supportive treatment against COVID-19 infection due to its anti-inflammatory, antioxidant as well as direct antiviral effects (28).

\section{VITAMIN D (VD)}

VD a fat-soluble vitamin, plays a vital role in both in immunomodulatory, antioxidant and antiviral responses (29, 30). The human airway epithelium constitutively expresses the vitamin $\mathrm{D}$ receptor thereby enabling the protective effects of $\mathrm{VD}$ against respiratory infections. VD blocks NF- $\mathrm{KB}$ p 65 activation via up-regulation of NF- $\mathrm{KB}$ inhibitory protein I-kappa-B-alpha $(\mathrm{IKB}-\alpha)(31)$. VD also decreases the expression levels of proinflammatory type 1 cytokines such as IL-12, IL-16, IL-8, TNF$\alpha$, IFN- $\gamma$ while increasing type 2 cytokines such as IL-4, IL-5, IL-10, and regulatory $\mathrm{T}$ cells $(32,33)$. VD increases the levels of antioxidant NRF-2 and facilitates balanced mitochondrial functions, prevents oxidative stress-related protein oxidation, lipid peroxidation and DNA damage (30).

Epidemiological data relates VD deficiency to increases in the susceptibility to acute viral respiratory infections (34) while its supplementation potentiates the innate immune responses to respiratory viral infections including those caused by Influenza $A$ and $B$, parainfluenza 1 and 2, respiratory syncytial virus (RSV), and chronic hepatitis C $(35,36)$. Though there are no reports that VD directly affects the virus replication or viral load, studies reveal that VD could contribute to antiviral activity through suppression of virus-induced inflammation. Perhaps this function of VD could help in suppression of the cytokine storm in SARS-CoV-2 infection. In a randomized controlled trial (RCT), VD supplementation of monthly high-dose $(100,000$ $\mathrm{IU} /$ month) in comparison to a standard dose (12,000 IU/month) helps in reducing the incidence of acute respiratory infections especially in older long-term care residents (37). Furthermore, evidence also suggests that VD can supplement the effectiveness of drug treatment as observed in the case of ribavirin therapy for treatment-naïve patients with chronic Hepatitis C virus (HCV) genotype 1 and $\mathrm{HCV}$ genotype $2 \mathrm{e} 3$ infections $(33,34,38,39)$. The beneficial effect of supplementation was seen in patients across all ages groups and in individuals with pre-existing chronic illness (40). Older people are most often deficient in these important micronutrients. Thus they can derive the most significant benefit from the VD supplementation (41).

\section{VITAMIN C (VC)}

Vitamin C can potentially protect against infection due to its essential role on immune health (42). This vitamin supports the function of various immune cells and enhances their ability to protect against infection. Supplementing with VC has been shown to reduce the duration and severity of upper respiratory infections (most of which are assumed to be due to viral infections), including the common cold (43). The recommended dose of VC varied from 1 to $3 \mathrm{~g} /$ day. The total recommended daily allowance (RDA) for VC is $60 \mathrm{mg}$. Various spices, herbs, fruits, and vegetables have found to be excellent sources of VC 
(44). For example, thyme fresh (267\%RDA), turmeric (43\%RDA), cardamom (35\%RDA), coriander (35\%RDA), beetroot juice are good sources of VC (45). VC is also a potent antioxidant. As an antioxidant, it scavenges ROS, prevents lipid peroxidation, and protein alkylation and thus protects cells from oxidative stress induced cellular damage (46). Studies also have revealed that administration of VC in combination with quercetin provides synergistic antiviral, antioxidant and immunomodulatory effects (47). Recently, based on the clinical trial it is proposed that the oral administration of $250-500 \mathrm{mg}$ quercetin, $500 \mathrm{mg}$ VC for high risk and mild symptomatic subjects twice a day for 7 days and up to $3 \mathrm{~g} \mathrm{VC}$ and $500 \mathrm{mg}$ quercetin twice a day for 7 days in ARDS patients (assisted ventilation/intubation) improves the overall recovery in SARS-CoV-2 subjects (47). Therefore, having the food supplement incorporated with sources of VC can help in alleviating and providing immune boosting as well as an anti-inflammatory, antioxidant effect against SARS-CoV-2 infection (48).

\section{CURCUMIN}

Curcumin has a broad spectrum of biological actions, including antibacterial, antiviral, antifungal, antioxidant and antiinflammatory activities (49). It inhibits the production of pro-inflammatory cytokines (IL-6 and TNF- $\alpha$ ) in lipopolysaccharide (LPS)-stimulated BV2 microglial cells (50) and IL- $1 \beta$ and IL- 6 in TNF- $\alpha$ treated HaCaT cells via inhibiting the NF- $\mathrm{KB}$ and MAPK signaling pathways (51). The curcumin also inhibits cyclooxygenase-2 (COX-2), as well as STAT signaling pathways (52). Curcumin exerts antiviral effect on a broad range of viruses including influenza virus, adenovirus, hepatitis, human papilloma virus (HPV), human immunodeficiency virus (HIV), herpes simplex virus-2 (HSV2) and Zika viruses (53). It exerts antiviral effect by various mechanisms ranging from inhibiting the virus entry into cells, inhibiting encapsulation of the virus and viral protease, inhibiting the virus replication, as well as modulating several signaling pathways (54). Recent study has shown that curcumin potentially inhibits ACE2, modulates characteristics of lipid bilayer, as well as viral S protein inhibiting entry of virus into cells $(54,55)$, inhibits the viral protease (56), stimulates host interferon production to activate the host innate immunity (55), etc. Furthermore, curcumin is a potent antioxidant. It exerts its antioxidant effects both by neutralizing free radicals and enhancing the production of antioxidant enzymes (57-60). These studies reveal potential immune-boosting, antioxidant and anti-SARS-CoV-2 effects of curcumin. Therefore, curcumin could be a potential supplement in combating the COVID-19 pathogenesis.

\section{CINNAMALDEHYDE}

Cinnamaldehyde is a naturally present organic compound abundantly found in essential oils in cinnamon. It predominantly exists in the trans-isomer form, which gives cinnamon its flavor and odor (61). Cinnamaldehyde is a well-known dietary phytonutrient, known to possess anti-inflammatory properties.
In a study by Liao et al. (62), it was found that cinnamaldehyde inhibits the TNF- $\alpha$-induced inflammation through suppression of NF- $\kappa \mathrm{B}$ activation. Studies have also found that it can suppress endotoxin-mediated hyperexpression of TLR4 and NOD-, LRRand pyrin domain-containing protein 3 (NLRP3) inflammasome signaling pathways (63). Cinnamaldehyde is also known to downregulate the production of prostaglandins (PGEs) by downregulating IL-1 $1 \beta$-induced COX- 2 activity thus lowering the chances of hyper inflammation in a dose-dependent manner (64). All the above evidences show cases that cinnamaldehyde is a potential anti-inflammatory bioactive compound and could be useful in mitigation of SARS-CoV-2 induced hyper inflammation in the lung.

\section{ALLICIN}

Garlic is a well-known plant/ herb classified under Allium (onion) family and has been used from ages for its several nutraceutical properties. The predominant thiosulfinate in fresh garlic extract identified as allicin, has shown a number of health benefits due to its anti-inflammatory, antioxidant and antiviral properties. Allicin suppresses the inflammation via inhibiting the TNF- $\alpha$ induced expression levels of IL-1 $1 \beta$, IL- 8 , IP- 10 , and IFN- $\gamma$ and also through suppression of degradation of NF- $\mathrm{\kappa B}$ inhibitory protein IкB in intestinal epithelial cells (65). It inhibits inducible NO nitric oxide synthase expression in activated macrophages $(66,67)$. Several garlic associated compounds have found to possess a strong viricidal activity against a wide range of viruses including parainfluenza virus type 3 , human rhinovirus, herpes simplex virus (HSV)-1, HSV-2, and vesicular stomatitis virus (VSV). Some of the garlic compounds that show viricidal activity are ajoene, allicin, allyl, methyl thiosulfinate and methyl allyl thiosulfinate $(68,69)$. Most of the above-mentioned functional effects were observed at $200 \mathrm{ng} / \mathrm{ml}$ concentrations. Studies also have found that only fresh samples with no processing such as heat induction or drying were successful to induce most of the biological activities of garlic (70). Therefore, fresh garlic extract may be useful as a prophylactic against COVID-19.

\section{PIPERINE}

Black pepper has long been used in many cuisines and it holds a very valuable space among medicinal plants. Piperine that is obtained from ethanolic extract of black pepper and is a major alkaloid in the group of cinnamamides (71). Piperine possesses a strong anti-inflammatory function and therefore can be repurposed for suppression of hyper inflammation induced during COVID-19. It downregulates PGEs by inhibiting the expression levels of IL-6 and matrix metalloproteinases (MMP13) (71). Piperine promotes innate immunity by promoting the phagocytic activity of phagocytes and is known to inhibit LPSinduced expression of IRF-1 and IRF-7 mRNA, phosphorylation of IRF-3, type 1IFN mRNA, and down-regulation of STAT-1 activity (72). Few studies conducted on microglial cells have shown that piperine inhibits LPS-Induced TNF- $\alpha$, IL-6, IL$1 \beta$, and PGE2 production in BV2 cells (73). Also, it found to 
inhibit the production of IL-2, and IFN- $\gamma$ in human peripheral blood mononuclear cells (PBMCs) (74). Furthermore, piperine treatment found to reduce the production of pro-inflammatory cytokines such as IL-1 $\beta$, IL-6, TNF- $\alpha$, COX-2, nitric oxide synthase-2, and NF- $\mathrm{KB}$ in the cerebral ischemia-reperfusioninduced inflammation rat model (75). These findings indicate the strong anti-inflammatory activity of the piperine. Further, piperine is a potent antioxidant and protects against oxidative damage by neutralizing free radicals, ROS, and hydroxyl radicals. It scavenges superoxide radicals with $\mathrm{IC}_{50}$ of $1.82 \mathrm{mM}$ and inhibits lipid peroxidation with $\mathrm{IC}_{50}$ of $1.23 \mathrm{mM}$. These results indicate that piperine possesses a direct antioxidant effect against various free radicals (76). Because of these properties, piperine can be tried as a prophylactic or therapeutic compound to protect from the oxidative stress and hyper inflammation induced during the COVID-19.

\section{SELENIUM (SE)}

Selenium is abundantly found in common foods such as corn, garlic, onion, cabbage, broccoli. It's an essential micronutrient that plays a vital role in various physiological processes and on the immune system. Selenium exerts its biological effect through incorporation into selenoproteins in the body. Optimum selenium status (100 $\mu \mathrm{g}$ per day) promotes enhanced $\mathrm{T}$ cell proliferation, NK cell activity and innate cell functions. Further supports stronger vaccine response and robust immunity to pathogens. Also, suppresses severe inflammation in tissues such as lungs and intestine (77). Studies have shown that selenium supplementation modulates the inflammatory response in respiratory distress syndrome patients by restoring the antioxidant status of the lungs and suppressing the IL- $1 \beta$ and IL-6 levels (78). Selenium supplementation suppresses pathogen induced activation of NF- $\kappa B$ and its downstream pro-inflammatory cytokine release (79). The antiviral properties of selenium have found to be mediated through its antioxidant effects. Selenium-deficient HIV+ patients tend to present with diminished antioxidant glutathione peroxidase activity (77). On the other hand, selenium supplementation demonstrates the improved $\mathrm{CD}+\mathrm{T}$ cell counts (80) and improves glutathione peroxidase and other antioxidant selenoenzymes along with catalase activities (81). Overall, selenium improves the immunity through its non-enzymatic role acting as cofactor for enzymes involved in critical post-translational modifications of proteins. Because of its substantial role in suppressing the inflammation and augmentation of antioxidant status and innate immunity, selenium supplementation may be useful in fight against COVID-19.

\section{PROPOLIS}

Propolis produced by honeybees and known to have a broad spectrum of biological properties, including anti-microbial, antiinflammatory, dermatoprotective, laxative, anti-diabetic, anti-tumor, and immunomodulatory activity (82). The immunomodulatory activity is attributed to flavonoids and some phenolic acids mainly caffeic acid phenethyl esters and artepillin C (3,5-diprenyl-4-hydroxycinnamic acid). Propolis exhibits immunomodulatory effects on a broad spectrum of immune cells mediated by the modulation of extracellular signalregulated kinase 2 and MAPK signaling pathways. Further, it also modulates nuclear factor of activated T cells (NFAT) and NF $\kappa \mathrm{B}$ signaling pathways $(82,83)$. Propolis also stimulates greater antibody production, suggesting that it could be used as an adjuvant in vaccines. Propolis at higher concentration inhibits lymphoproliferation while at low concentrations the effect is reversed, causing lymphoproliferation (84). Further, compounds in honey propolis inhibits various viruses such as dengue virus type 2, herpes simplex virus, human cytomegalovirus, influenza virus A1 (85). Together, with immunomodulatory and antiviral effects, propolis can be tried as a prophylactic support against COVID-19.

\section{PROBIOTICS}

The commonly used probiotics are Bifidobacterium and Lactobacillus species, followed by the Streptococcus, Enterococcus, Bacillus, and Escherichia coli. Probiotics not only support the health of the gut but also improves system functioning and regulation (86). Though it is not clear how gut microbiome provides benefit over respiratory tract infections via gut-lung axis. In general, it is observed that the gut microbiome impacts systemic immune responses as well as local immune responses at distal mucosal sites, including lungs (87). Consumption of Bifidobacterium and Lactobacillus have found to help in clearing the influenza virus in the respiratory tract (88). Levels of interferons, mucosal antibodies of lung and activity of NK cells, antigen presenting cells (APCs) are improved by probiotics (89). Lactobacillus plantarum DR7 strain has shown to have suppressing effect on the pro-inflammatory cytokines TNF- $\alpha$, IFN- $\gamma$, enhances anti-inflammatory cytokines IL-10, IL-4 and also known to reduce plasma peroxidation levels as well as modulate immune system (90). It is reported that Lactobacillus acidophilus CMCC878 administration in mice infected with Staphylococcus aureus, and Pseudomonas aeruginosa decreased the damage in the lungs by reducing the bacterial load and reducing the inflammation (91). A clinical study has reported that administration of Leuconostoc mesenteroides 32-77:1, Lactobacillus plantarum 2,362, L. paracasei ssp. paracasei 19, Pediococcus pentosaceus 5-33:3 along with resistant starch, inulin prebiotics etc. reduced systemic inflammatory response syndrome and other infections (92). Bifidobacterium longum BB536 strain prevents infection from influenza and improves innate immunity (93). Though mechanism of their immunomodulating and anti-inflammatory effects in the lung are not clearly understood. In general, probiotics exert anti-inflammatory and immunomodulatory effects via modulation of the NF- $\mathrm{B}$, MAPK and pattern recognition receptors (PRR) pathways that decreases Th2 mediated responses and upregulates Th1 responses. Further, they have an ability to inhibit the attachment of bacterial LPS to $\mathrm{CD} 14$ receptor, hence decrease in the overall activation of 
NF- $\kappa \mathrm{B}$ and pro-inflammatory cytokines production $(94,95)$. Considering the role of probiotics in improving the host innate immune response as well as anti-inflammatory effects (87), and considering the fact that gut involvement and enterocytes (96) can be reservoirs of SARS-CoV-2 infection, probiotics can be repurposed as prophylactics as well as adjuvants to combat the pathogenesis of COVID-19.

\section{LACTOFERRIN}

Lactoferrin (Lf) is a naturally occurring and non-toxic glycoprotein that has been studied against a broad range of viruses, including SARS-CoV, which is closely related to SARSCoV-2. Lf inhibits viral entry via binding to cell surface molecules or viral particles or both. It was also known to suppress virus replication as in the case of HIV. Therefore, it plays a crucial role in preventing the virus entry and replication (97). Studies have shown that it exerts immunomodulatory and antioxidant effects by inducing the T-cell activation, suppressing the levels of interleukins including IL- 6 , TNF- $\alpha$, and downregulating the ferritin (98). Also it suppresses $\mathrm{H}_{2} \mathrm{O}_{2}$-induced oxidative stress in human umbilical vein endothelial cells (99). Furthermore, zinc saturated Lf exerts a more potent antiviral effect (100). It is mainly used as a nutritional additive in infant formulas and clinical studies, with doses ranging from $100 \mathrm{mg}$ to $4.5 \mathrm{~g}$

TABLE 1 | Summary of food supplements and their major functional effects.

\begin{tabular}{|c|c|c|c|}
\hline $\begin{array}{l}\text { Serial } \\
\text { number }\end{array}$ & Food supplements & Properties & $\begin{array}{l}\text { Status of the } \\
\text { clinical trial }\end{array}$ \\
\hline 1 & Zinc (Zn) (Antiviral) & $\begin{array}{l}\text { - Protects against oxidative stress and inhibit TNF- } \alpha \text {, IFN- } \gamma \text {, FasR and JAK-STAT signaling pathways. } \\
\text { - Modulates the viral entry, fusion, replication, viral protein translation and virus budding of respiratory viruses. }\end{array}$ & Phase 1 and 2 \\
\hline 2 & $\begin{array}{l}\text { Vitamin D (VD) } \\
\text { (Immune-boosting } \\
\text { anti-inflammatory) }\end{array}$ & $\begin{array}{l}\text { - Blocks NF-кB p65 activation via up-regulation of I-kappa-B-alpha (IKB- } \alpha \text { ). } \\
\text { - Decreases the expression of the pro-inflammatory type } 1 \text { cytokines: IL-12, IL-16, IL-8, TNF- } \alpha \text { and IFN- } \gamma \\
\text { and increases type } 2 \text { cytokines IL-4, IL-5, IL-10. } \\
\text { - Upregulates the levels of antioxidant NRF-2, facilitates balanced mitochondrial functions. }\end{array}$ & Phase 2 \\
\hline 3 & $\begin{array}{l}\text { Vitamin C (VC) } \\
\text { (Immune-boosting, } \\
\text { antioxidant) }\end{array}$ & $\begin{array}{l}\text { - Decreases pro-inflammatory cytokines, TNF- } \alpha \text { and IFN- } \gamma \text { and increases anti-inflammatory IL-10 production. } \\
\text { - Reduces the duration and severity of upper respiratory infections (viral infections). } \\
\text { - Scavenges ROS, prevents lipid peroxidation, and protein alkylation and thus protect cells from oxidative } \\
\text { stress induced cellular damage. }\end{array}$ & Phase 2 \\
\hline 4 & $\begin{array}{l}\text { Curcumin } \\
\text { (Immune-boosting, } \\
\text { antiviral, } \\
\text { anti-inflammatory, and } \\
\text { antioxidant) }\end{array}$ & $\begin{array}{l}\text { - Stimulates host interferon production to activate the host innate immunity. } \\
\text { - Binds to S protein at RBD and ACE2 receptor and inhibits virus entry. } \\
\text { - Inhibits NF-кB, cyclinD1, COX-2, TNF- } \alpha \text {, and STAT signaling pathways. } \\
\text { - Neutralizes free radicals and enhances the production of antioxidant enzymes. }\end{array}$ & Phase 1 and 2 \\
\hline 5 & $\begin{array}{l}\text { Cinnamaldehyde } \\
\text { (Anti-inflammatory) }\end{array}$ & $\begin{array}{l}\text { - Suppress the NF-кB, TLR4, and NLRP3 signaling pathways. } \\
\text { - Downregulates the production of prostaglandins. }\end{array}$ & Phase 2 \\
\hline 6 & $\begin{array}{l}\text { Allicin (Antiviral, } \\
\text { anti-inflammatory) }\end{array}$ & $\begin{array}{l}\text { - Downregulates the proinflammatory cytokines and inhibits the nitric oxide synthase expression in } \\
\text { macrophages. } \\
\text { - Possess antiviral effect on broad spectrum of viruses of HSV family, parainfluenza virus and } \\
\text { human rhinovirus. }\end{array}$ & Phase 1 and 2 \\
\hline 7 & $\begin{array}{l}\text { Piperine } \\
\text { (Anti-inflammatory and } \\
\text { antioxidant) }\end{array}$ & 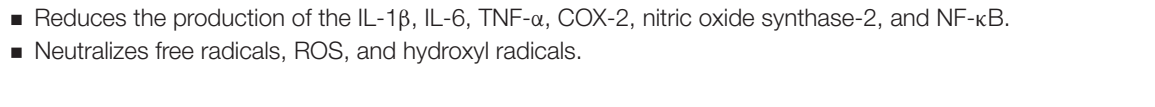 & Phase 2 \\
\hline 8 & $\begin{array}{l}\text { Selenium } \\
\text { (Immune-boosting, and } \\
\text { antioxidant) }\end{array}$ & $\begin{array}{l}\text { - Promotes the } T \text { cell proliferation, NK cell activity and innate cell function. } \\
\text { - It downregulates the proinflammatory cytokines (IL-1 } 1 \beta \text { and IL-6). } \\
\text { - Augments glutathione peroxidase and other antioxidant selenoenzymes activities. }\end{array}$ & Phase 2 \\
\hline 9 & $\begin{array}{l}\text { Propolis } \\
\text { (Immune-boosting, } \\
\text { anti-inflammatory) }\end{array}$ & $\begin{array}{l}\text { Exhibits the immunomodulatory effect through extracellular signal-regulated kinase } 2 \text { and MAPK pathways } \\
\text { and by modulating the NFAT and NF-кB activation. } \\
\text { Inhibits various viruses such as dengue virus type } 2 \text {, herpes simplex virus, human cytomegalovirus, } \\
\text { influenza virus A1. }\end{array}$ & \\
\hline 10 & $\begin{array}{l}\text { Probiotics (Immune } \\
\text { boosting, } \\
\text { anti-inflammatory) }\end{array}$ & $\begin{array}{l}\text { - Lactobacillus plantarum DR7 suppress proinflammatory cytokines TNF- } \alpha \text {, IFN- } \gamma \text {, enhances } \\
\text { anti-inflammatory cytokines IL-10, IL-4. } \\
\text { - Lactobacillus acidophilus CMCC878 reduces the bacterial load and inflammation in mice lungs infected } \\
\text { with staphylococcus and pseudomonas. } \\
\text { - Leuconostoc mesenteroides } 32-77: 1, \text { L. plantarum 2,362, L. paracasei ssp. paracasei 19, Pediococcus } \\
\text { pentosaceus 5-33:3 along with resistant starch, inulin etc reduce systemic inflammatory response } \\
\text { syndrome and other infections. } \\
\text { - Bifidobacterium longum BB536 prevents infection from influenza and improves innate immunity. }\end{array}$ & Phase 2 \\
\hline 11 & Lactoferrin (antiviral) & $\begin{array}{l}\text { Downregulates the IL-6, TNF- } \alpha \text {, and ferritin. } \\
\text { Inhibits the viral entry and suppress the viral replication. }\end{array}$ & Phase 1 and 2 \\
\hline 12 & Quercetin (antiviral) & $\begin{array}{l}\text { - Inhibits the production of the TNF- } \alpha, \mathrm{IL}-8, \mathrm{IL}-1 \alpha, \mathrm{COX} \text {, and LOX enzymes. } \\
\text { - Possesses antiviral effects against both RNA (influenza and coronavirus) and DNA viruses (herpesvirus). } \\
\text { - Act as ligand for the S protein of virus and ACE } 2 \text { and interferes in binding of virus to cells. }\end{array}$ & Phase 1 and 2 \\
\hline
\end{tabular}


TABLE 2 | Registered clinical trials of food supplements (Source: ClinicalTrials.gov).

\begin{tabular}{|c|c|c|}
\hline $\begin{array}{l}\text { Serial } \\
\text { number }\end{array}$ & $\begin{array}{l}\text { Food } \\
\text { supplements }\end{array}$ & Registered clinical trials for COVID-19 \\
\hline 1 & Zinc (Zn) & $\begin{array}{l}\text { 1. Evaluation of the Relationship Between Zinc Vitamin D and b12 Levels in the COVID-19 positive Pregnant Women (Pinar Yalcin Bahat } \\
\text { Istanbul, Istanbul, Turkey). } \\
\text { 2. Zinc with Chloroquine/Hydroxychloroquine in Treatment of COVID-19 (Tanta University hospital Tanta, Egypt). } \\
\text { 3. A Study of Hydroxychloroquine, Vitamin C, Vitamin D, and Zinc for the Prevention of COVID-19 Infection (Progena Biome Ventura, } \\
\text { California, United States). }\end{array}$ \\
\hline 3 & $\begin{array}{l}\text { Vitamin C } \\
\text { (VC) }\end{array}$ & $\begin{array}{l}\text { 1. Administration of Intravenous Vitamin C in the Novel Coronavirus Infection (COVID-19) and Decreased Oxygenation (Hunter Holmes } \\
\text { Mcguire veteran Affairs Medical Center Richmond, Virginia, United States). } \\
\text { 2. A Study of Hydroxychloroquine, Vitamin C, Vitamin D, and Zinc for the Prevention of COVID-19 Infection (ProgenaBiome Ventura, } \\
\text { California, United States). } \\
\text { 3. The Study of Quadruple Therapy Zinc, Quercetin, Bromelain and Vitamin C on the Clinical Outcomes of Patients Infected With } \\
\text { COVID-19 (Ministry of Health. First health cluster, Riyadh, Riyadh, Saudi Arabia). }\end{array}$ \\
\hline 5 & Probiotics & $\begin{array}{l}\text { 1. Effect of Lactobacillus on the Microbiome of Household Contacts Exposed to COVID-19 (Duke University Durham, North Carolina, } \\
\text { United States). } \\
\text { 2. Oxygen-Ozone as Adjuvant Treatment in Early Control of COVID-19 Progression and Modulation of the gut Microbial Flora (Francesco } \\
\text { Pugliese Rome, RM Italy). } \\
\text { 3. Evaluation of the Probiotic Lactobacillus Coryniformis K8 on COVID-19 Prevention in Healthcare Workers (Raquel Rodrigues Blanque } \\
\text { Granada, Spain). } \\
\text { 4. Study to Evaluate the Effect of a Probiotic in COVID-19 (Hospital Universitario de Vinalopo Elache, Alicante, Spain, Hospital } \\
\text { Universitario de Torrevieja Torreviveja, Alicante, Spain). }\end{array}$ \\
\hline 6 & Quercetin & $\begin{array}{l}\text { 1. Effect of Quercetin on Prophylaxis and Treatment of COVID-19 (Kanuni Sultan Suleyman Training and Research Hospital Istanbul, Turkey). } \\
\text { 2. The Study of Quadruple Therapy Zinc, Quercetin Bromelain and Vitamin C on the Clinical Outcomes of Patients Infected With COVID-19 } \\
\text { (Ministry of Health. First Health cluster, Riyadh. Riyadh, Saudi Arabia). } \\
\text { 3. Estrogen Patch for COVID-19 Symptoms (Stony Brook University Hospital, Stony Brook, New York. USA). }\end{array}$ \\
\hline
\end{tabular}

a day for various indications without apparent toxicities. and can be tried as a potential preventive and therapeutics against COVID-19 (98).

\section{QUERCETIN}

Quercetin is a well-known antioxidant with anti-inflammatory and antiviral bioactive. It inhibits TNF- $\alpha$ production in LPSinduced macrophages (101), IL-8 production in lung A549 cells (102), and mRNA levels of TNF- $\alpha$ and IL- $1 \alpha$ in glial cells (103). It also limits the production of cyclooxygenase (COX) and lipoxygenase (LOX) enzymes in rat liver epithelial cells (104). Studies have also shown that quercetin has antiviral effects on both RNA and DNA viruses. It inhibits the virus entry and viral-cell fusion (105) and reduces the expression of pro-inflammatory cytokines and lung inflammation induced by rhinovirus in mice (106). Further, quercetin metabolite (4,5diacetyloxy-3,3,7-trimethoxyflavone) has been shown to inhibit the picornavirus replication by inhibiting the RNA replicase complex (107). Studies have also found that quercetin-3 $\beta$ galactoside due to the presence of hydroxyl group, it binds to viral protease $3 \mathrm{CL}_{\text {pro }}$ and inhibits its proteolytic activity (108). In the context of SARS virus infection, supercomputer SUMMIT drug-docking screen and gene set enrichment analyses (GSEA) finds that quercetin, VD, and estradiol interferes the functioning of 85,70 and $61 \%$ of the SARS-CoV-2 viral proteins in human cells, respectively. Based on these observations the study also predicts tripartite combination (quercetin/VD/estradiol) compared to bipartite (VD/quercetin) of may affect $73 \%$ human genes encoding SARS-CoV-2 targets implicating a robust mitigating agents against the COVID-19 (109). Further, increased ability of estradiol in affecting human genes encoding SARS-CoV-2 targets compared to testosterone suggests a plausible explanation of the apparently higher male mortality in this corona pandemic (109). In line with these observations, a randomized interventional clinical trial using estradiol or VD as a mitigating agent have been listed on the clinical trial (https://clinicaltrials.gov/ct2/show/NCT04359329).

Furthermore, as observed in prediction models that quercetin binds SARS-CoV-2 S-protein at its host receptor region or to the S-protein-human ACE2 interface interfering the virus entry into cells indicating its therapeutic potential (110). This prediction is consistent with the reports that both quercetin and a structurally similar luteolin inhibits the SARS-CoV virus infection (111). Additionally, other studies have also found that quercetin in combination with VC induces synergistic antiviral and immunomodulatory effects against COVID-19 (47). Taken together, various studies suggest that quercetin possesses potential anti-SARS-CoV-2 effects and can be repurposed as a preventive and therapeutic candidate to combat COVID-19. 


\section{CONCLUSIONS}

Currently, there is one corona vaccine, Sputnik V, developed by the Gamaleya Research Institute, Moscow has been approved by the Ministry of Health, Russian Federation. It was fasttracked for use as a corona vaccine, but experts have expressed concern about the vaccine's efficacy and safety since it has not yet been evaluated in phase 3 clinical trials. Presently, there are over 100 vaccines around the world in various stages of research and development. A few of them are in human clinical trials and are being tested rigorously for their safety, efficacy, and dosage standardization. Similarly, there are several drug candidates that have been identified and most are in various stages of research and development, whilst some of them have been repurposed and approved for emergency use in this pandemic. The notable ones approved for use in an emergency include hydroxychloroquine, favipiravir, remdesivir, tocilizumab, etc., Furthermore, no substantial research supports the use of specific food supplements as adjuvant therapy for the management of COVID-19 subjects. The plethora of existing literature provides the scientific evidence on immune-boosting, antiinflammatory, antioxidant, and antiviral properties of several phytonutrients as summarized in Table 1. Initial studies find that some of these have been found to possess anti-SARS-CoV-2

\section{REFERENCES}

1. Chan JFW, Yuan S, Kok KH, To KKW, Chu H, Yang J, et al. A familial cluster of pneumonia associated with the 2019 novel coronavirus indicating person-to-person transmission: a study of a family cluster. Lancet. (2020) 395:514-23. doi: 10.1016/S0140-6736(20)30154-9

2. Guan WJ, Ni ZY, Hu Y, Liang WH, Ou CQ, He JX, et al. Clinical characteristics of coronavirus disease 2019 in China. N Engl J Med. (2020) 382:1708-20. doi: 10.1056/NEJMoa2002032

3. Li Q, Guan X, Wu P, Wang X, Zhou L, Tong Y, et al. Early transmission dynamics in Wuhan, China, of novel coronavirus-infected pneumonia. $N$ Engl J Med. (2020) 382:1199-207. doi: 10.1056/NEJMoa2001316

4. Shi Y, Wang Y, Shao C, Huang J, Gan J, Huang X, et al. COVID-19 infection: the perspectives on immune responses. Cell Death Differ. (2020) 27:1451-4. doi: 10.1038/s41418-020-0530-3

5. Hoffmann M, Kleine-Weber H, Schroeder S, Krüger N, Herrler T, Erichsen $S$, et al. SARSCoV-2 cell entry depends on ace 2 and tmprss 2 and is blocked by a clinically proven protease inhibitor. Cell. (2020) 181:271-80.e8. doi: 10.1016/j.cell.2020.02.052

6. Ou X, Liu Y, Lei X, Li P, Mi D, Ren L, et al. Characterization of spike glycoprotein of SARSCoV-2 on virus entry and its immune cross-reactivity with SARSCoV. Nat Commun. (2020) 11:1620. doi: 10.1038/s41467-020-15562-9

7. Channappanavar R, Perlman S. Pathogenic human coronavirus infections: causes and consequences of cytokine storm and immunopathology. Semin Immunopathol. (2017) 39:529-39. doi: 10.1007/s00281-0170629-x

8. Kindler E, Thiel V, Weber F. Interaction of SARS and MERS coronaviruses with the antiviral interferon response. Adv Virus Res. (2016) 96:21943. doi: 10.1016/bs.aivir.2016.08.006

9. Li X, Geng M, Peng Y, Meng L, Lu S. Molecular immune pathogenesis and diagnosis of COVID-19. J Pharm Anal. (2020) 10:102-8. doi: 10.1016/j.jpha.2020.03.001

10. Olagnier D, Farahani E, Thyrsted J, Cadanet JB, Herengt A, Idorn M, et al. Identification of SARSCoV2-mediated suppression of NRF2 signaling effects and are being fast-tracked into clinical trials (Table 2). Repurposing of these nutrients in the right combination to achieve the functional synergy in the form of ready-to-eat food supplements may provide both prophylactic and adjuvant therapy against COVID-19.

\section{AUTHOR CONTRIBUTIONS}

MM, VP, RN, and PJ: drafted the article. PH and PVR: edited the article. All authors: contributed to the article and approved the submitted version.

\section{FUNDING}

This study was supported by the Department of Biotechnology (DBT)-Ramalingaswami Fellowship (BT/HRD/35/02/2006), Department of Science and Technology-Science and Engineering Research Board (DST-SERB) (EMR/2016/007994), Govt. of India.

\section{ACKNOWLEDGMENTS}

We are thankful to the Director and to CSIR-CFTRI for providing facilities to carry out this study. reveals a potent antiviral and anti-inflammatory activity of 4-octyl-itaconate and dimethyl fumarate. bioRxiv. (2020). doi: 10.21203/rs.3.rs-31855/v1

11. Delgado-Roche L, Mesta F. Oxidative stress as key player in severe acute respiratory Syndrome Coronavirus (SARSCoV) infection. Arch Med Res. (2020) 51:384-7. doi: 10.1016/j.arcmed.2020.04.019

12. Ntyonga-Pono MP. COVID-19 infection and oxidative stress: an underexplored approach for prevention and treatment? Pan Afr Med J. (2020) 35:12. doi: 10.11604/pamj.2020.35.2.22877

13. Lin CW, Lin KH, Hsieh TH, Shiu SY, Li JY. Severe acute respiratory syndrome coronavirus 3C-like protease-induced apoptosis. FEMS Immunol Med Microbiol. (2006) 46:375-80. doi: 10.1111/j.1574-695X.2006.00045.x

14. Wu YH, Tseng CP, Cheng ML, Ho HY, Shih SR, Chiu DTY. Glucose6-phosphate dehydrogenase deficiency enhances human coronavirus 229E infection. J Infect Dis. (2008) 197:812-6. doi: 10.1086/528377

15. Bell TJ, Brand OJ, Morgan DJ, Salek-Ardakani S, Jagger C, Fujimori T, et al. Defective lung function following influenza virus is due to prolonged, reversible hyaluronan synthesis. Matrix Biol J Int Soc Matrix Biol. (2019) 80:14-28. doi: 10.1016/j.matbio.2018.06.006

16. Wang D, Hu B, Hu C, Zhu F, Liu X, Zhang J, et al. Clinical characteristics of 138 hospitalized patients with 2019 novel coronavirus-infected pneumonia in Wuhan, China. JAMA. (2020) 323:1061-9. doi: 10.1001/jama.20 20.1585

17. Xu Z, Shi L, Wang Y, Zhang J, Huang L, Zhang C, et al. Pathological findings of COVID-19 associated with acute respiratory distress syndrome. Lancet Respir Med. (2020) 8:420-2. doi: 10.1016/S2213-2600(20)30076-X

18. Hällgren R, Samuelsson T, Laurent TC, Modig J. Accumulation of hyaluronan (hyaluronic acid) in the lung in adult respiratory distress syndrome. Am Rev Respir Dis. (1989) 139:6827. doi: $10.1164 / \mathrm{ajrccm} / 139.3 .682$

19. Read SA, Obeid S, Ahlenstiel C, Ahlenstiel G. The role of zinc in antiviral immunity. Adv Nutr. (2019) 10:696-710. doi: 10.1093/advances/nmz013

20. Biaggio VS, Pérez Chaca MV, Valdéz SR, Gómez NN, Gimenez MS. Alteration in the expression of inflammatory parameters as a result of oxidative stress produced by moderate zinc deficiency in rat lung. Exp Lung Res. (2010) 36:31-44. doi: 10.3109/01902140903061787 
21. Bao S, Knoell DL. Zinc modulates cytokine-induced lung epithelial cell barrier permeability. Am J Physiol Lung Cell Mol Physiol. (2006) 291:L113241. doi: 10.1152/ajplung.00207.2006

22. Liu MJ, Bao S, Napolitano JR, Burris DL, Yu L, Tridandapani S, et al. Zinc regulates the acute phase response and serum amyloid a production in response to sepsis through JAKSTAT3 signaling. PLoS ONE. (2014) 9:e94934. doi: 10.1371/journal.pone.0094934

23. Ishida $\mathrm{T}$. Review on the role of $\mathrm{Zn} 2^{+}$ions in viral pathogenesis and the effect of $\mathrm{Zn}^{+}$ions for host cell-virus growth inhibition. Am J Biomed Sci Res. (2019) 2:28-37. doi: 10.34297/AJBSR.2019.02.000566

24. Speth R, Carrera E, Jean-Baptiste M, Joachim A, Linares A. Concentration-dependent effects of zinc on angiotensinconverting enzyme-2 activity (1067.4). FASEB J. (2014) 28:1067.4. doi: 10.1096/fasebj.28.1_supplement.1067.4

25. te Velthuis AJW, van den Worm SHE, Sims AC, Baric RS, Snijder EJ, van Hemert MJ. $\mathrm{Zn}^{+}$inhibits coronavirus and arterivirus RNA polymerase activity in vitro and zinc ionophores block the replication of these viruses in cell culture. PLoS Pathog. (2010) 6:e1001176. doi: 10.1371/journal.ppat.1001176

26. Hemilä H, Fitzgerald JT, Petrus EJ, Prasad A. Zinc acetate lozenges may improve the recovery rate of common cold patients: an individual patient data meta-analysis. Open Forum Infect Dis. (2017) 4:ofx059. doi: 10.1093/ofid/ofx059

27. Roth DE, Richard SA, Black RE. Zinc supplementation for the prevention of acute lower respiratory infection in children in developing countries: metaanalysis and meta-regression of randomized trials. Int J Epidemiol. (2010) 39:795-808. doi: 10.1093/ije/dyp391

28. Zhang L, Liu Y. Potential interventions for novel coronavirus in China: a systematic review. J Med Virol. (2020) 92:479-90. doi: 10.1002/jmv. 25707

29. Prietl B, Treiber G, Pieber TR, Amrein K. Vitamin D and immune function. Nutrients. (2013) 5:2502-21. doi: 10.3390/nu5072502

30. Wimalawansa SJ. Vitamin D deficiency: effects on oxidative stress, epigenetics, gene regulation, and aging. Biology. (2019) 8:30. doi: $10.3390 /$ biology8020030

31. Chen Y, Zhang J, Ge X, Du J, Deb DK, Li YC. Vitamin D receptor inhibits nuclear factor $\mathrm{\kappa B}$ activation by interacting with IкB kinase $\beta$ protein. J Biol Chem. (2013) 288:19450-8. doi: 10.1074/jbc.M113.467670

32. Lemire JM, Archer DC, Beck L, Spiegelberg HL. Immunosuppressive actions of 1,25-dihydroxyvitamin D3: preferential inhibition of Th1 functions. $J$ Nutr. (1995) 125:1704S-8. doi: 10.1016/0960-0760(95)00106-A

33. Jeffery LE, Burke F, Mura M, Zheng Y, Qureshi OS, Hewison M, et al. 1, 25-Dihydroxyvitamin D3 and IL-2 combine to inhibit T cell production of inflammatory cytokines and promote development of regulatory $\mathrm{T}$ cells expressing CTLA-4 and FoxP3. J Immunol Baltim Md 1950. (2009) 183:5458-67. doi: 10.4049/jimmunol.0803217

34. Monlezun DJ, Bittner EA, Christopher KB, Camargo CA, Quraishi SA. Vitamin D status and acute respiratory infection: cross sectional results from the United States National Health and Nutrition Examination Survey, 2001-2006. Nutrients. (2015) 7:1933-44. doi: 10.3390/nu7031933

35. Zdrenghea MT, Makrinioti H, Bagacean C, Bush A, Johnston SL, Stanciu LA. Vitamin D modulation of innate immune responses to respiratory viral infections. Rev Med Virol. (2017) 27. doi: 10.1002/rmv.1909

36. Abu-Mouch S, Fireman Z, Jarchovsky J, Zeina AR, Assy N. Vitamin D supplementation improves sustained virologic response in chronic hepatitis C (genotype 1)-naïve patients. World J Gastroenterol. (2011) 17:518490. doi: 10.3748/wjg.v17.i47.5184

37. Ginde AA, Blatchford P, Breese K, Zarrabi L, Linnebur SA, Wallace JI, et al. High-dose monthly vitamin D for prevention of acute respiratory infection in older long-term care residents: a randomized clinical trial. J Am Geriatr Soc. (2017) 65:496-503. doi: 10.1111/jgs.14679

38. Behera MK, Shukla SK, Dixit VK, Nath P, Abhilash VB, Asati PK, et al. Effect of vitamin $\mathrm{D}$ supplementation on sustained virological response in genotype $1 / 4$ chronic hepatitis C treatment-naïve patients from India. Indian J Med Res. (2018) 148:200-6. doi: 10.4103/ijmr.IJMR_1295_15

39. Nimer A, Mouch A. Vitamin D improves viral response in hepatitis C genotype 2-3 naïve patients. World J Gastroenterol WJG. (2012) 18:8005. doi: $10.3748 /$ wjg.v18.i8.800
40. Charan J, Goyal JP, Saxena D, Yadav P. Vitamin D for prevention of respiratory tract infections: a systematic review and meta-analysis. $J$ Pharmacol Pharmacother. (2012) 3:300-3. doi: 10.4103/0976-500X.103685

41. Goncalves-Mendes N, Talvas J, Dualé C, Guttmann A, Corbin V, Marceau G, et al. Impact of vitamin D supplementation on influenza vaccine response and immune functions in deficient elderly persons: a randomized placebo-controlled trial. Front Immunol. (2019) 10:65. doi: 10.3389/fimmu.2019.00065

42. Carr AC, Maggini S. Vitamin C and immune function. Nutrients. (2017) 9:1211. doi: 10.3390/nu9111211

43. van Driel ML, Beller EM, Thielemans E, Deckx L, Price-Haywood E, Clark J, et al. Oral vitamin C supplements to prevent and treat acute upper respiratory tract infections. Cochrane Database Syst Rev. (2019) 2019:CD013292. doi: 10.1002/14651858.CD013292

44. Vázquez-Fresno R, Rosana ARR, Sajed T, Onookome-Okome T, Wishart NA, Wishart DS. Herbs and spices- biomarkers of intake based on human intervention studies - a systematic review. Genes Nutr. (2019) 14:18. doi: 10.1186/s12263-019-0636-8

45. USDA National Nutrient Database. Foods highest in Vitamin $C$ and Iron in Spices and Herbs. (2008). Available online at: https://nutritiondata.self.com/ foods-002101119000000000000-1w.html (accessed May 27, 2020).

46. Traber MG, Stevens JF. Vitamins $\mathrm{C}$ and E: beneficial effects from a mechanistic perspective. Free Radic Biol Med. (2011) 51:1000-13. doi: 10.1016/j.freeradbiomed.2011.05.017

47. Colunga Biancatelli RML, Berrill M, Catravas JD, Marik PE. Quercetin and vitamin $\mathrm{C}$ : an experimental, synergistic therapy for the prevention and treatment of SARSCoV-2 related disease (COVID-19). Front Immunol. (2020) 11:1451. doi: 10.3389/fimmu.2020.01451

48. Hunt C, Chakravorty NK, Annan G, Habibzadeh N, Schorah CJ. The clinical effects of vitamin C supplementation in elderly hospitalised patients with acute respiratory infections. Int J Vitam Nutr Res. (1994) 64:212-9.

49. Catanzaro M, Corsini E, Rosini M, Racchi M, Lanni C. Immunomodulators inspired by nature: a review on curcumin and echinacea. Molecules. (2018) 23:2778. doi: 10.3390/molecules23112778

50. Jin CY, Lee JD, Park C, Choi YH, Kim GY. Curcumin attenuates the release of pro-inflammatory cytokines in lipopolysaccharidestimulated BV2 microglia. Acta Pharmacol Sin. (2007) 28:164551. doi: 10.1111/j.1745-7254.2007.00651.x

51. Cho JW, Lee KS, Kim CW. Curcumin attenuates the expression of IL-1beta, IL-6, and TNF-alpha as well as cyclin E in TNF-alpha-treated HaCaT cells; NF-kappaB and MAPKs as potential upstream targets. Int J Mol Med. (2007) 19:469-74. doi: 10.3892/ijmm.19.3.469

52. Ghosh S, Banerjee S, Sil PC. The beneficial role of curcumin on inflammation, diabetes and neurodegenerative disease: a recent update. Food Chem Toxicol. (2015) 83:111-24. doi: 10.1016/j.fct.2015.05.022

53. Chen TY, Chen DY, Wen HW, Ou JL, Chiou SS, Chen JM, et al. Inhibition of enveloped viruses infectivity by curcumin. PLoS ONE. (2013) 8:e62482. doi: 10.1371/journal.pone.0062482

54. Zahedipour F, Hosseini SA, Sathyapalan T, Majeed M, Jamialahmadi T, AlRasadi K, et al. Potential effects of curcumin in the treatment of COVID-19 infection. Phytother Res PTR. (2020). doi: 10.1002/ptr.6738

55. Ting D, Dong N, Fang L, Lu J, Bi J, Xiao S, et al. multisite inhibitors for enteric coronavirus: antiviral cationic carbon dots based on curcumin. ACS Appl Nano Mater. (2018) 1:5451-9. doi: 10.1021/acsanm.8b00779

56. Khaerunnisa S, Kurniawan H, Awaluddin R, Suhartati S, Soetjipto S. Potential inhibitor of COVID-19 Main Protease (Mpro) from several medicinal plant compounds by molecular docking study. Nat Prod Bioprospect. (2020) 1-10. doi: 10.20944/preprints202003.0226.v1

57. Menon VP, Sudheer AR. Antioxidant and anti-inflammatory properties of curcumin. Adv Exp Med Biol. (2007) 595:10525. doi: 10.1007/978-0-387-46401-5_3

58. Barclay LR, Vinqvist MR, Mukai K, Goto H, Hashimoto Y, Tokunaga A, et al. On the antioxidant mechanism of curcumin: classical methods are needed to determine antioxidant mechanism and activity. Org Lett. (2000) 2:2841-3. doi: 10.1021/ol000173t

59. Agarwal R, Goel SK, Behari JR. Detoxification and antioxidant effects of curcumin in rats experimentally exposed to mercury. J Appl Toxicol. (2010) 30:457-68. doi: 10.1002/jat.1517 
60. Biswas SK, McClure D, Jimenez LA, Megson IL, Rahman I. Curcumin induces glutathione biosynthesis and inhibits NF-kappaB activation and interleukin-8 release in alveolar epithelial cells: mechanism of free radical scavenging activity. Antioxid Redox Signal. (2005) 7:3241. doi: 10.1089/ars.2005.7.32

61. Rao PV, Gan SH. Cinnamon: a multifaceted medicinal plant. Evid-Based Complement Altern Med. (2014) 2014:642942. doi: 10.1155/2014/642942

62. Liao BC, Hsieh CW, Liu YC, Tzeng TT, Sun YW, Wung BS. Cinnamaldehyde inhibits the tumor necrosis factor-alpha-induced expression of cell adhesion molecules in endothelial cells by suppressing NF-kappaB activation: effects upon IkappaB and Nrf2. Toxicol Appl Pharmacol. (2008) 229:16171. doi: 10.1016/j.taap.2008.01.021

63. Lee SC, Wang SY, Li CC, Liu CT. Anti-inflammatory effect of cinnamaldehyde and linalool from the leaf essential oil of Cinnamomum osmophloeum Kanehira in endotoxin-induced mice. J Food Drug Anal. (2018) 26:211-20. doi: 10.1016/j.jfda.2017.03.006

64. Guo JY, Huo HR, Zhao BS, Liu HB, Li LF, Ma YY, et al. Cinnamaldehyde reduces IL-1beta-induced cyclooxygenase-2 activity in rat cerebral microvascular endothelial cells. Eur J Pharmacol. (2006) 537:174-80. doi: 10.1016/j.ejphar.2006.03.002

65. Lang A, Lahav M, Sakhnini E, Barshack I, Fidder HH, Avidan B, et al. Allicin inhibits spontaneous and TNF-alpha induced secretion of proinflammatory cytokines and chemokines from intestinal epithelial cells. Clin Nutr Edinb Scotl. (2004) 23:1199-208. doi: 10.1016/j.clnu.2004.03.011

66. Shin JH, Ryu JH, Kang MJ, Hwang CR, Han J, Kang D. Short-term heating reduces the anti-inflammatory effects of fresh raw garlic extracts on the LPS-induced production of NO and pro-inflammatory cytokines by downregulating allicin activity in RAW 264.7 macrophages. Food Chem Toxicol. (2013) 58:545-51. doi: 10.1016/j.fct.2013.04.002

67. Dirsch VM, Gerbes AL, Vollmar AM. Ajoene, a compound of garlic, induces apoptosis in human promyeloleukemic cells, accompanied by generation of reactive oxygen species and activation of nuclear factor kappaB. Mol Pharmacol. (1998) 53:402-7. doi: 10.1124/mol.53.3.402

68. Galabov AS. Virucidal agents in the eve of manorapid synergy. GMS Krankenhaushyg Interdiszip. (2007) 2:Doc18.

69. Weber ND, Andersen DO, North JA, Murray BK, Lawson LD, Hughes BG. In vitro virucidal effects of Allium sativum (garlic) extract and compounds. Planta Med. (1992) 58:417-23. doi: 10.1055/s-2006-961504

70. Siegers CP, Röbke A, Pentz R. Effects of garlic preparations on superoxide production by phorbol ester activated granulocytes. Phytomedicine. (1999) 6:13-6. doi: 10.1016/S0944-7113(99)80029-4

71. Bang JS, Oh DH, Choi HM, Sur BJ, Lim SJ, Kim JY, et al. Anti-inflammatory and antiarthritic effects of piperine in human interleukin lbeta-stimulated fibroblast-like synoviocytes and in rat arthritis models. Arthritis Res Ther. (2009) 11:R49. doi: 10.1186/ar2662

72. Bae GS, Kim MS, Jung WS, Seo SW, Yun SW, Kim SG, et al. Inhibition of lipopolysaccharide-induced inflammatory responses by piperine. Eur J Pharmacol. (2010) 642:154-62. doi: 10.1016/j.ejphar.2010.05.026

73. Wang-Sheng C, Jie A, Jian-Jun L, Lan H, Zeng-Bao X, Chang-Qing L. Piperine attenuates lipopolysaccharide (LPS)-induced inflammatory responses in BV2 microglia. Int Immunopharmacol. (2017) 42:448. doi: 10.1016/j.intimp.2016.11.001

74. Chuchawankul S, Khorana N, Poovorawan Y. Piperine inhibits cytokine production by human peripheral blood mononuclear cells. Genet Mol Res. (2012) 11:617-27. doi: 10.4238/2012.March.14.5

75. Vaibhav K, Shrivastava P, Javed H, Khan A, Ahmed ME, Tabassum R, et al. Piperine suppresses cerebral ischemia-reperfusion-induced inflammation through the repression of COX-2, NOS-2, and NF- $\mathrm{B}$ in middle cerebral artery occlusion rat model. Mol Cell Biochem. (2012) 367:7384. doi: 10.1007/s11010-012-1321-z

76. Mittal R, Gupta RL. In vitro antioxidant activity of piperine. Methods Find Exp Clin Pharmacol. (2000) 22:271-4. doi: 10.1358/mf.2000.22.5.796644

77. Avery JC, Hoffmann PR. Selenium, selenoproteins, and immunity. Nutrients. (2018) 10:1203. doi: 10.3390/nu10091203

78. Mahmoodpoor A, Hamishehkar H, Shadvar K, Ostadi Z, Sanaie S, Saghaleini $\mathrm{SH}$, et al. The effect of intravenous selenium on oxidative stress in critically Ill patients with acute respiratory distress syndrome. Immunol Invest. (2019) 48:147-59. doi: 10.1080/08820139.2018.1496098
79. Dhanjal NI kaur, Sharma S, Prabhu KS, Prakash NT. Selenium supplementation through Se-rich dietary matrices can upregulate the anti-inflammatory responses in lipopolysaccharide-stimulated murine macrophages. Food Agric Immunol. (2017) 28:137492. doi: 10.1080/09540105.2017.1343805

80. Stone CA, Kawai K, Kupka R, Fawzi WW. Role of Selenium in HIV infection. Nutr Rev. (2010) 68:671-81. doi: 10.1111/j.1753-4887.2010.00337.x

81. Dworkin BM. Selenium deficiency in HIV infection and the acquired immunodeficiency syndrome (AIDS). Chem Biol Interact. (1994) 91:1816. doi: 10.1016/0009-2797(94)90038-8

82. Wolska K, Gorska A, Antosik K, Lugowska K. Immunomodulatory effects of propolis and its components on basic immune cell functions. Indian J Pharm Sci. (2019) 81:575-88. doi: 10.36468/pharmaceutical-sciences.548

83. Sforcin JM, Bankova V. Propolis: is there a potential for the development of new drugs? J Ethnopharmacol. (2011) 133:253-60. doi: 10.1016/j.jep.2010.10.032

84. Sforcin JM. Propolis and the immune system: a review. J Ethnopharmacol. (2007) 113:1-14. doi: 10.1016/j.jep.2007.05.012

85. Amoros M, Lurton E, Boustie J, Girre L, Sauvager F, Cormier M. Comparison of the anti-herpes simplex virus activities of propolis and 3-Methyl-but-2enyl caffeate. J Nat Prod. (1994) 57:644-7. doi: 10.1021/np50107a013

86. Schreck Bird A, Gregory PJ, Jalloh MA, Risoldi Cochrane Z, Hein DJ. probiotics for the treatment of infantile colic: a systematic review. J Pharm Pract. (2017) 30:366-74. doi: 10.1177/0897190016634516

87. Zelaya H, Alvarez S, Kitazawa H, Villena J. Respiratory antiviral immunity and immunobiotics: beneficial effects on inflammation-coagulation interaction during influenza virus infection. Front Immunol. (2016) 7:633. doi: 10.3389/fimmu.2016.00633

88. Baud D, Dimopoulou Agri V, Gibson GR, Reid G, Giannoni E. Using probiotics to flatten the curve of coronavirus disease COVID-2019 pandemic. Front Public Health. (2020) 8:186. doi: 10.3389/fpubh.2020. 00186

89. Mortaz E, Adcock IM, Folkerts G, Barnes PJ, Paul Vos A, Garssen J. Probiotics in the management of lung diseases. Mediators Inflamm. (2013) 2013:751068. doi: 10.1155/2013/751068

90. Chong HX, Yusoff NAA, Hor YY, Lew LC, Jaafar MH, Choi SB, et al. Lactobacillus plantarum DR7 improved upper respiratory tract infections via enhancing immune and inflammatory parameters: a randomized, double-blind, placebo-controlled study. J Dairy Sci. (2019) 102:478397. doi: 10.3168/jds.2018-16103

91. Shoaib A, Xin L, Xin Y. Oral administration of Lactobacillus acidophilus alleviates exacerbations in Pseudomonas aeruginosa and Staphylococcus aureus pulmonary infections. Pak J Pharm Sci. (2019) 32:1621-30.

92. Kotzampassi K, Giamarellos-Bourboulis EJ, Voudouris A, Kazamias P, Eleftheriadis E. Benefits of a synbiotic formula (Synbiotic 2000Forte) in critically Ill trauma patients: early results of a randomized controlled trial. World J Surg. (2006) 30:1848-55. doi: 10.1007/s00268-005-0653-1

93. Namba K, Hatano M, Yaeshima T, Takase M, Suzuki K. Effects of Bifidobacterium longum BB536 administration on influenza infection, influenza vaccine antibody titer, and cell-mediated immunity in the elderly. Biosci Biotechnol Biochem. (2010) 74:939-45. doi: 10.1271/bbb. 90749

94. Sharma G, Im SH. Probiotics as a potential immunomodulating pharmabiotics in allergic diseases: current status and future prospects. Allergy Asthma Immunol Res. (2018) 10:57590. doi: 10.4168/aair.2018.10.6.575

95. Hajavi J, Esmaeili SA, Varasteh AR, Vazini H, Atabati H, Mardani F, et al. The immunomodulatory role of probiotics in allergy therapy. J Cell Physiol. (2019) 234:2386-98. doi: 10.1002/jcp.27263

96. Lin L, Jiang X, Zhang Z, Huang S, Zhang Z, Fang Z, et al. Gastrointestinal symptoms of 95 cases with SARSCoV-2 infection. Gut. (2020) 69:9971001. doi: 10.1136/gutjnl-2020-321013

97. Rosa L, Cutone A, Lepanto MS, Paesano R, Valenti P. Lactoferrin: a natural glycoprotein involved in iron and inflammatory homeostasis. Int J Mol Sci. (2017) 18:1985. doi: 10.3390/ijms18091985

98. Ishikado A, Imanaka H, Takeuchi T, Harada E, Makino T. Liposomalization of lactoferrin enhanced it's anti-inflammatory effects via oral administration. Biol Pharm Bull. (2005) 28:1717-21. doi: 10.1248/bpb.28.1717 
99. Safaeian L, Javanmard SH, Mollanoori Y, Dana N. Cytoprotective and antioxidant effects of human lactoferrin against $\mathrm{H} 2 \mathrm{O} 2$-induced oxidative stress in human umbilical vein endothelial cells. Adv Biomed Res. (2015) 4:188. doi: 10.4103/1735-5362.192488

100. Li S, Zhou H, Huang G, Liu N. Inhibition of HBV infection by bovine lactoferrin and iron-, zinc-saturated lactoferrin. Med Microbiol Immunol (Berl). (2009) 198:19-25. doi: 10.1007/s00430-008-0100-7

101. Manjeet KR, Ghosh B. Quercetin inhibits LPS-induced nitric oxide and tumor necrosis factor-alpha production in murine macrophages. Int $J$ Immunopharmacol. (1999) 21:435-43. doi: 10.1016/S0192-0561(99)00024-7

102. Geraets L, Moonen HJJ, Brauers K, Wouters EFM, Bast A, Hageman GJ. Dietary flavones and flavonoles are inhibitors of poly(ADPribose)polymerase-1 in pulmonary epithelial cells. J Nutr. (2007) 137:2190-5. doi: 10.1093/jn/137.10.2190

103. Bureau G, Longpré F, Martinoli MG. Resveratrol and quercetin, two natural polyphenols, reduce apoptotic neuronal cell death induced by neuroinflammation. J Neurosci Res. (2008) 86:403-10. doi: 10.1002/jnr.21503

104. Lee KM, Hwang MK, Lee DE, Lee KW, Lee HJ. Protective effect of quercetin against arsenite-induced COX-2 expression by targeting PI3K in rat liver epithelial cells. J Agric Food Chem. (2010) 58:5815-20. doi: 10.1021/jf903698s

105. Wu W, Li R, Li X, He J, Jiang S, Liu S, et al. Quercetin as an antiviral agent inhibits influenza A Virus (IAV) entry. Viruses. (2015) 8:6. doi: 10.3390/v8010006

106. Ganesan S, Faris AN, Comstock AT, Wang Q, Nanua S, Hershenson MB, et al. Quercetin inhibits rhinovirus replication in vitro and in vivo. Antiviral Res. (2012) 94:258-71. doi: 10.1016/j.antiviral.2012.03.005

107. Antipicornavirus flavone Ro 09-0179. Antimicrobial Agents and Chemotherapy. Available online at: https://aac.asm.org/content/22/4/ 611 (accessed July 26, 2020).
108. Chen L, Li J, Luo C, Liu H, Xu W, Chen G, et al. Binding interaction of quercetin-3- $\beta$-galactoside and its synthetic derivatives with SARSCoV 3CLpro: structure-activity relationship studies reveal salient pharmacophore features. Bioorg Med Chem. (2006) 14:8295306. doi: 10.1016/j.bmc.2006.09.014

109. Glinsky GV. Tripartite combination of candidate pandemic mitigation agents: vitamin $\mathrm{D}$, quercetin, and estradiol manifest properties of medicinal agents for targeted mitigation of the COVID-19 pandemic defined by genomics-guided tracing of SARSCoV-2 targets in human cells. Biomedicines. (2020) 8:129. doi: 10.26434/chemrxiv.12052512.v7

110. Smith M, Smith JC. Repurposing therapeutics for COVID-19: supercomputer-based docking to the SARSCoV-2 viral spike protein and viral spike protein-human ACE2 interface. ChemRxiv [Preprint]. (2020). doi: 10.26434/chemrxiv.11871402.v2

111. Yi L, Li Z, Yuan K, Qu X, Chen J, Wang G, et al. Small molecules blocking the entry of severe acute respiratory syndrome coronavirus into host cells. $J$ Virol. (2004) 78:11334-9. doi: 10.1128/JVI.78.20.11334-11339.2004

Conflict of Interest: The authors declare that the research was conducted in the absence of any commercial or financial relationships that could be construed as a potential conflict of interest.

Copyright (c) 2020 Mrityunjaya, Pavithra, Neelam, Janhavi, Halami and Ravindra. This is an open-access article distributed under the terms of the Creative Commons Attribution License (CC BY). The use, distribution or reproduction in other forums is permitted, provided the original author(s) and the copyright owner(s) are credited and that the original publication in this journal is cited, in accordance with accepted academic practice. No use, distribution or reproduction is permitted which does not comply with these terms. 